\title{
Development of a Metal-Organic Framework for the Sensitive Determination of 2,4-Dichlorophenol
}

\author{
Meng Cui ${ }^{1,2}$, Jingtong $\mathrm{Li}^{2}$, Dayong $\mathrm{Lu}^{2, *}$, Ziqiang Shao ${ }^{1, *}$ \\ ${ }^{1}$ Beijing Engineering Research Center of Cellulose and Its Derivatives, School of Materials Science \\ and Engineering, Beijing Institute of Technology, Beijing, 100081, P.R. China \\ ${ }^{2}$ College of Materials Science and Engineering, Jilin Institute of Chemical Technology Research \\ Center for Materials Science and Engineering, Jijin, 132022, P.R. China \\ *E-mail: $\underline{\text { cm860502@163.com }}$
}

doi: $10.20964 / 2018.04 .48$

Received: 10 December 2017 / Accepted: 30 January 2018 / Published: 6 March 2018

The present study proposed a facile and highly sensitive electrochemical sensor based on a carbon paste electrode modified by the metal-organic framework (MOF) $\left[\mathrm{Cu}(\mathrm{bpy})\left(\mathrm{H}_{2} \mathrm{O}\right)_{2}\left(\mathrm{BF}_{4}\right)_{2}\right.$ (bpy)] for the analysis of 2,4-dichlorophenol (2,4-DCP). X-ray diffraction (XRD) and Fourier transform infrared spectrometry (FT-IR) were used to investigate the morphology and composition, respectively, of $\left[\mathrm{Cu}(\mathrm{bpy})\left(\mathrm{H}_{2} \mathrm{O}\right)_{2}\left(\mathrm{BF}_{4}\right)_{2}(\mathrm{bpy})\right]$. Additionally, cyclic voltammetry $(\mathrm{CV})$ was carried out to study the electrochemical performance. Considering the high charge transfer efficiency, strong adsorption capacity and large specific surface area of $\left[\mathrm{Cu}(\right.$ bpy $)\left(\mathrm{H}_{2} \mathrm{O}\right)_{2}(\mathrm{BF} 4)_{2}($ bpy $\left.)\right]$, our developed sensor was favorably selective to the detection of 2,4-DCP under optimum parameters, with a wide linear range of 4 to $100 \mu \mathrm{M}$ and a low limit of detection (LOD) of $1.1 \mu \mathrm{M}$.

Keywords: Metal-organic frameworks; $\left[\mathrm{Cu}(\right.$ bpy $)\left(\mathrm{H}_{2} \mathrm{O}\right)_{2}\left(\mathrm{BF}_{4}\right)_{2}($ bpy $\left.)\right]$; 2,4-dichlorophenol; Electrochemical determination; Sensor

\section{$\underline{\text { FULL TEXT }}$}

(C) 2018 The Authors. Published by ESG (www.electrochemsci.org). This article is an open access article distributed under the terms and conditions of the Creative Commons Attribution license (http://creativecommons.org/licenses/by/4.0/). 